\title{
Entrepreneurial Competencies and Growth of New Micro Small and Medium Businesses
}

\author{
Raja Mejri' ${ }^{1}$, Mahmoud Zouaoui $^{2}$ \\ ${ }^{1}$ Department of Management Information Systems, College of Business, University of Jeddah, Jeddah, KSA \\ ${ }^{2}$ Department of Management, Tunis Business School, University of Manouba, Tunis, Tunisia \\ Email: rajamejri@yahoo.fr, mahmoudzouaoui.esct@gmail.com
}

How to cite this paper: Mejri, R., \& Zouaoui, M. (2020). Entrepreneurial Competencies and Growth of New Micro Small and Medium Businesses. Open Journal of Business and Management, 8, 1151-1163. https://doi.org/10.4236/ojbm.2020.83074

Received: February 8, 2020

Accepted: May 9, 2020

Published: May 12, 2020

Copyright (c) 2020 by author(s) and Scientific Research Publishing Inc. This work is licensed under the Creative Commons Attribution International License (CC BY 4.0).

http://creativecommons.org/licenses/by/4.0/

(c) (i) Open Access

\begin{abstract}
Encouraging the creation of companies has become the leitmotif for solving the economic and social problems of states, especially when it comes to companies with real potential for growth, which constitutes the real levers of countries development. We focus on the profile of entrepreneurs who create small businesses and who can successfully increase their projects after a few years. They are the pillars of success insofar as the company is the projection of their characteristics. This document attempts to better understand the impact of entrepreneurial competencies on the growth of the company. The research was carried out using a questionnaire sent to 181 micro, small and medium-sized enterprises (MSME's) newly created. For the analysis of the results we have mobilized the method of structural equations. The results confirmed that the growth of the company is well influenced by managerial and networking competencies.
\end{abstract}

\section{Keywords}

Entrepreneur, Competencies, Micro Small and Medium Enterprises, Growth

\section{Introduction}

In recent years, the creation of businesses has been encouraged as it becomes the leitmotif for economic and social states' problems-solving (Boudreaux et al., 2019; Scuotto et al., 2019). Henceforth, the unprecedented support of the private is initiated especially for those entrepreneurs who have projects with potential growth (Lindič et al., 2012). Numerous researches have effectively proven that companies which manage to grow are the real levers of the economies development (Duthil \& Vanhaecke, 1993). Their proliferation is considered as an indicator of countries health (Moore, 1993). According to the GEM program, the ef- 
fect of companies that manage to grow is mainly counted with regard of job creation, innovation and restructuring of economies (GEM, 2018). However, most companies lack the competencies that allow them to be competitive in the market; hence the alarming failure rates occur, especially during the first 5 years of their existence (Lambert, 2019). For all these reasons, we have been pushed to deepen this issue to better understand which competencies determine the growth of the newly created companies (Nuscheler et al., 2019; Loufrani-Fedida et al., 2019).

To conduct this research, we chose to mobilize the behaviorist approach as well as the resource-based view approach, which gave more convincing results with the valuation of the competencies mobilized by the company especially those possessed by the entrepreneur, mainly when we deal with small structures, which largely depend on the founder. So, the central aim of this paper is to identify which competencies that contribute the most to rapid growth of Micro, Small \& Medium Enterprises?

The paper is structured as follows. First, we highlight the importance of competencies in the performance of the company, especially those of the entrepreneur. Then, in the second part, we will present our methodological framework, to finish with the analysis and discussion of the results obtained and some recommendations.

\section{Literature Review}

\subsection{Growth Determinants of Enterprises: Entrepreneur's Role}

Analysis of literature has shown that studying the performance of companies and particularly their growth remains a complex issue. Indeed, the phenomenon affects many factors related to 1 ) entrepreneur's profile: psychological, demographic, educational, and experiential, 2) company's characteristics and managerial's style, and 3) the environment in which the company has evolved (Paturel, 1997). This paper proposes to concentrate on the person of the entrepreneur, the keystone of entrepreneurial success as much as we deal about small units (Ndjambou \& Sassine, 2014) which remain a projection of the characteristics of leaders (Chabaud \& Sammut, 2016).

In the beginning, research in entrepreneurship focused on the person of the entrepreneur was launched mainly by the scholars with psychological and sociological backgrounds. This current recognized by the trait approach has adopted a descriptive orientation by promoting the psychological characteristics of entrepreneurs to explain the success of their businesses (Barba-Sánchez \& Martínez-Ruiz, 2009). Among the most identified characteristics, we find: the need for autonomy, the need for accomplishment, the desire to take up challenges, and the desire to enrich one-self, etc. However, the weak results of these current, prompted scholars to dig into other directions. Indeed, with the rise of the behaviorist approach in the mid-1990s, the interest is in actions rather than in the "innate" characteristics of the entrepreneur (Gartner, 1989). Emphasis is now placed on the competencies of the entrepreneur, which prove better pre- 
dictors of performance. It should be noted that during this period, there was the development of the Resource-Based View (RBV) approach, which advocated the development of competencies for better competitiveness on the market (Teece et al., 1997).

\subsection{Role of Competencies in Business Growth of Micro, Small \& Medium Enterprises}

To explain companies performance, management literature has started to take an interest in the concept of competence at the 1960s (Bayad et al., 2007), However, the link with the entrepreneurship's field was made only in the 1990s, with the behaviorist approach (Fayolle et al., 2008) which considers studying entrepreneurial competencies the best way to identify the profile of the successful entrepreneurs (Kellermanns et al., 2008). At first, the scholars tried to point out the key competencies then they began presenting more structured work, such as typological studies (Nkakleu et al., 2013). We join Carrier and Tremblay (2007) who point out that the typology of Chandler and Jansen (1992) remains among the few to have obtained the approval of the research community, that is why we chose to adopt it in this research. The authors of the typology built their study on 134 entrepreneurs and were able to identify five central competencies determining the performance of the company: managerial, identifying and exploiting opportunities, asserting one's position in a network of companies, intensive work and mastering the functional and technical aspects related to business.

\subsubsection{Managerial Competency and Firm Growth}

Over the years, there has been a growing literature on managerial competencies which can be defined regarding of knowledge, skills, experiences and personal characteristics (Bhardwaj, 2013), but the research proposed by Henri Fayol and Henri Mintzberg remove the pillars of modern management. Fayol has set out 14 general management principles, divided into 5 key functions: planning, organization, command, coordination, and control. Mintzberg has identified 9 key competencies referred to 3 main roles: interpersonal, informational, and decision-making (Mowll, 1989).

In this paper, we consider managerial competencies as the ability of the entrepreneur to evaluate a project, determine its feasibility, and manage it efficiently to generate a profit or a social utility (Carrier \& Tremblay, 2007).

A number of scholars show positive relationship between the managerial competencies and the organization's performance (Hawi et al., 2015). They are important for achieving strategic organizational goals and viewed as sources a competitive advantage (Königová et al., 2012).

In light of the above, we state hypothesis H.1: The managerial competencies of the entrepreneur positively influence the growth of the business.

\subsubsection{Opportunity Identification Competence and Firm Growth}

Ge et al. (2016) recognize the entrepreneur by his ability to identify and exploit 
business opportunities to transform them into profitable activities. In the same vein Sabai and Tau (2018: p. 6) think that "entrepreneurs need to be able to recognize and exploit the market opportunity to start their new business or launch a new product because their product or service needs to fit the market need and available resources well". Baron and Markman (2003) stipulate that the ability to identify opportunities with high potential increases the performance of new businesses. The authors emphasize the importance of identifying obstacles before they become insurmountable, and argue that inequality in the cognitive processes of entrepreneurs makes the difference when it comes to monitoring, and processing information, especially face of ambiguity.

In light of the above, we state hypothesis H.2: Identifying and seizing opportunities positively influence the growth of the business.

\subsubsection{Network Competence and Firm Growth}

The network competencies are "the ability of entrepreneurs to develop and maintain long-term relationships with customers, suppliers, and other interested stakeholders" (Sajilan \& Tehseen, 2019: p. 192).

According to Das and Goswami (2019) many studies have argued that the performance of small firms depends on the help of people who can provide the support to identify opportunities and access to resources in the market. Networking boosts the business and allows it to easily fill in the missing resources: it feeds the companies with forward-looking information that helps reduce uncertainty in business (Human \& Provan, 1994), facilitates access to knowledge, technology and power (Kusumawardhani et al., 2009) and it helps to raise financial funds at a lower cost (Bah, 2008).

According to Janssen (2011), networking with others companies are associated with a higher growth rate since they allow better synergies, and reduce the costs and risks associated with the project. Zhao and Aram (1995) consider it as the main characteristics of high-growth SMEs.

In light of the above, we state Hypothesis H.3: Networking competencies positively influence business growth.

\subsubsection{Drive to See Venture Through to Frution and Firm Growth}

The creation of a new business is a permanent challenge where success depends mainly on the persistence of entrepreneurs. These latter encounter major obstacles with uncertain results, and their ability to resist and to manage adversity predicts their personal effectiveness and their performance (Baron \& Markman, 2003). According to authors, to be successful, entrepreneurs must rise above obstacles and must work intensively despite uncertain results.

Fortin (1992) argues that entrepreneurs are known for their energetic and hard-working nature which allows them to maintain a vigorous work rhythm for relatively long periods. Those who succeed to set up businesses with high growth potential have a high level of determination and consistency, which enables them to find solutions to the multiple obstacles encountered (Kiggundu, 2002). 
This strong commitment is often positively linked to the long-term performance of the SME (Man et al., 2008) and is one of the most important factors for ensuring the growth of the company (Dobbs \& Hamilton, 2007).

In light of the above, we state hypothesis H.4: Intense work of the entrepreneur positively influences the growth of the business.

\subsubsection{Functional and Technical Competence and Firm Growth}

Functional and technical competencies are crucial to manage the classic functions that make up businesses. According to Carrier and Tremblay (2007), these competencies refer to a set of concrete and technical knowledge such as the ability to know his product well, the ability to identify and master the key success factors in his field, the ability to follow trends in market, etc.

Researchers showed that these competencies are mobilized in both creation and management and have a positive relationship with the organization's performance of small businesses (Nkakleu, 2018). For example, Gasse and d'Amboise (1998) noted that entrepreneurs who succeed in growing their businesses have shown high technology competence, which have enabled them to make successful choices regarding sources of technology, either the purchase of R\&D license contracts, partnerships, and alliances.

In light of the above, we state hypothesis H.5: The functional and technical competencies of the entrepreneur positively influence the growth of the business.

\subsection{Measuring of Firm Growth}

By studying the phenomenon of growth, scholars realize that it is not a common phenomenon. Indeed, the percentage of companies that manage to reach this stage remains quite low even in developed countries, which increases the difficulty of our task, especially since the phenomenon is not perceived in the same way by the academics (Brush et al., 2009). According literature, the phenomenon was studied in two aspects. First, the qualitative aspect; which is manifested by changes in the characteristics of the company, such as the nature of the products and services offered, the nature of the presence on the market, and the mode of organization adopted. Secondly, we have the quantitative aspect, more apparent, which is manifested by a multitude of indicators expressing the size of the company such as turnover, workforce, added value, profit, etc. (Davidsson et al., 2007). As far as we are concerned in this study, the second part will be adopted. We view growth as an evolution in the size of the company through the turnover indicator (Chandler et al., 2009). It is the most adopted measure according to scholars given its accessibility (Delmar et al., 2003) and also the most acclaimed by managers (Janssen, 2011).

After showing how Important is small growing businesses for the development of the economies, we put forward the role of the entrepreneurs in the growth of their businesses, especially for small projects, where we concentrated 
our research on entrepreneur's competencies. We have developed five hypotheses to examine the relationships between the entrepreneur's competencies and the growth of the companies. The competencies examined were related to managerial competencies, identification and exploitation of opportunities, networking, intensive work and mastering the functional and technical aspects related to business. We note that the study was anchored on Chandler and Jansen's typology (Chandler \& Jansen, 1992). To measure the growth of the company, we choose a quantitative indicator, the increase in the turnover of the company since its creation.

\section{Research Methodology}

For the analysis of the collected data, we used 2 software: SPSS 17.0 for exploratory analysis and XLSTAT 2015 for confirmatory analysis via the PLS-PM approach.

\subsection{Population and Sample Size}

The study adopted a quantitative research design. Data was obtained through online surveys. The questionnaires were sent to the founders of 181 Tunisian micro, small and medium-sized enterprises (MSMEs). All the companies were incubated when they were launched in one of the 28 incubators under the aegis of the Tunisian Agency for the Promotion of Industry and Innovation (APII). It's a public establishment, responsible for the implementation of the Government's policies relative to the industrial sector and it provides a support structure for companies and promoters.

We successfully interviewed 104 companies. All the companies were the fruit of a creation ex-nihilo and newly created. Their age was between 3 and 5 years.

\subsection{Measures of Variables}

For the entrepreneur competencies variable we used the scale developed by Chandler and Jansen (1992) composed of 21 items spread over five variables: managerial competencies, competencies related to identifying and exploiting opportunities, asserting one's position in a network of companies, intensive work, and mastering the functional and technical aspects related to business. We proposed to the entrepreneurs interviewed a self-assessment of their competencies when launching their businesses on a Likert scale with 5 points ranging from "strongly agree" to "strongly disagree".

For the business growth variable, we have chosen the turnover indicator, which is widely acclaimed by scholars dealing with issues of business growth as well as managers. However, we were forced to resort to a subjective measure because of the reluctance of many interviewed to provide us with quantified financial data. We opted for the adaptation of the growth measurement used by Janssen (2005) by the proposal of a 4 points measurement scale on which the entrepreneur chooses the growth rate that he was able to achieve since the creation of 
his company, and this for a period ranging from 3 to 5 years.

\section{Analysis and Discussion of Results}

\subsection{The Demographic Profile of the Entrepreneurs}

As shown in Table 1, our sample is made up mainly of men, who represent $83.7 \%$ of respondents, which is favorable to the growth of the company. In fact numerous studies have shown that men are more attracted than women to the growth of their business (Shelton, 2006). Our sample is composed also of young companies: $46.2 \%$ were 5 years old, $45.2 \%$, were 4 years old and $8.7 \%$ were 3 years old. These companies are, as it was announced earlier, the result of an ex-nihilo creation, which makes them legally independent on any pre-existing structure. This form of creation remains the most difficult to implement and depends entirely on its founder. We notice that many scholars point out that the youth of the company is supposed to have a positive impact on its growth (Woywode \& Lessat, 2001).

Likewise, we noted that more than half of the interviewed entrepreneurs (67.3\%) already had a job before entering the business world. The rest either just finished their studies $(7.7 \%)$ or were unemployed (25\%). It should be noted that a pre-professional experience before embarking on an entrepreneurial career is always beneficial for the entrepreneur, especially when it is in the same environment (Colombo \& Grilli, 2010). It allows to move faster and more safely, and helps to gain the trust of key partners, customers, suppliers, and bankers... more easily.

\subsection{Exploratory Factor Analysis}

Before testing our analytical model, a principal component analysis (PCA) was carried out. The analysis confirmed the multidimensional structure of the scale

Table 1. Description of the studied sample.

\begin{tabular}{clc}
\hline \multicolumn{2}{c}{ Gender } & \\
\hline & Male & $83.7 \%$ \\
- & Female & $16.3 \%$ \\
& Age & \\
- & $<30$ & $39.4 \%$ \\
- & {$[31,40]$} & $44.2 \%$ \\
- & {$[41,50]$} & $14.4 \%$ \\
- & $>50$ & $1.9 \%$ \\
Situation of entrepreneurs before the creation of the business & \\
- & Student & $7.7 \%$ \\
- & Unemployed & $25.0 \%$ \\
- & Employee & $67.3 \%$ \\
\hline
\end{tabular}


used, namely the 5 dimensions. However, 3 items have been eliminated. These are items whose communality was less than 0.5 . The dimensions retained restored $71.4 \%$ of the explained variance and the analysis of the internal consistency of the factors through Cronbach's alpha, revealed globally acceptable coefficients, ranging from 0.62 to 0.94 .

\subsection{Confirmatory Factor Analysis}

After verifying the psychometric quality of the variables as shown in Table 2, we moved onto the analysis of the measurement model and the structural model.

For the measurement model, it was generally acceptable. As shown in Table 2 the analysis of internal consistency of the latent variables with the Dillon-Goldstein's rhon was acceptable for all the variables in the model: $(>0.8)$. Subsequently, we examined the convergent validity and discriminant validity of the variables which were also acceptable.

For the analysis of the structural model, we started by assessing the predictive validity of the global model by analyzing the Goodness of Fit indices (GoF) as shown in Table 3. We have found that absolute and relative GoF before and after high bootstrap were very close which testifies the stability of the model. The GoFs for internal and external models were also strong and very close which indicates a good quality of the links between the measurement variables and the latent variables. Finally, we noticed that all the critical ratios were above the threshold of 1.96, which confirms the good quality of fit of the model to the data and attests to its good predictive power.

We end the analysis by examining the causal relationships linking the latent variables of the research model as shown in Table 4.

Table 2. Composite reliability.

\begin{tabular}{ccc}
\hline Latent variable & Dimensions & Dillon-Goldstein's rho \\
\hline Mangerial & 5 & 0.945 \\
Opportunity & 4 & 0.958 \\
Hard working & 2 & 0.844 \\
Network & 3 & 0.943 \\
Funct \& tech & 2 & 0.944 \\
Growth & 1 & -
\end{tabular}

Table 3. GoF quality.

\begin{tabular}{ccccc}
\hline & GoF & GoF (Bootstrap) & Standard Erreur & Critical Ratio (CR) \\
\hline Absolute & 0.643 & 0.655 & 0.059 & 10.805 \\
Relative & 0.902 & 0.875 & 0.054 & 16.664 \\
Outer model & 0.990 & 0.974 & 0.023 & 43.530 \\
Inner model & 0.911 & 0.898 & 0.047 & 19.425 \\
\hline
\end{tabular}


Table 4. Path coefficients.

\begin{tabular}{cccccc}
\hline $\begin{array}{c}\text { Latent } \\
\text { Variable }\end{array}$ & Value & $\begin{array}{c}\text { Standard } \\
\text { Erreur }\end{array}$ & $\mathrm{T}$ & $\operatorname{Pr}>|\mathrm{t}|$ & $\begin{array}{c}\text { Critical Ratio } \\
(\mathrm{CR})\end{array}$ \\
\hline Mangerial & $\mathbf{0 . 5 2 8}$ & $\mathbf{0 . 0 9 5}$ & $\mathbf{5 . 5 5 5}$ & $\mathbf{0 . 0 0 0}$ & $\mathbf{6 . 7 7 6}$ \\
Opportunity & 0.066 & 0.092 & 0.717 & 0.475 & 0.771 \\
Hard working & 0.034 & 0.073 & 0.463 & 0.645 & 0.523 \\
Network & $\mathbf{0 . 2 2 1}$ & $\mathbf{0 . 0 8 0}$ & $\mathbf{2 . 7 7 2}$ & $\mathbf{0 . 0 0 7}$ & $\mathbf{2 . 6 7 5}$ \\
Funct \& tech & 0.053 & 0.072 & 0.745 & 0.458 & 0.587 \\
$\mathrm{R}^{2}$ & & $\mathbf{F}$ & $\operatorname{Pr}>\mathbf{F}$ & $\mathrm{R}^{2}$ (Bootstrap) & Standard Erreur \\
0.510 & & $\mathbf{2 0 . 4 2 9}$ & $\mathbf{0 . 0 0 0}$ & $\mathbf{0 . 5 4 3}$ & $\mathbf{0 . 0 8 8}$ \\
\hline
\end{tabular}

We note that the coefficient of determination, was acceptable $\left(\mathrm{R}^{2}=0.510\right)$, which allows us to say that the growth variable is well explained.

As we can see from the table below, the variables that influence the growth of the business are the managerial competencies, and the networking competencies, which allow us to confirm only the hypotheses: H.1 and H.3.

The study revealed a significant positive impact between managerial competencies and networking competencies on the growth of the business. However, there is no significant impact on competencies related to the identification and exploitation of opportunities, intense work, and technical, and functional competencies.

\section{Conclusion}

As we have shown, the comprehension of the competencies that contribute the most to the rapid growth of Micro, Small \& Medium Enterprises becomes crucial. These businesses are considered as the most promoters of the economy of countries. In this paper, we have formulated five research hypotheses to identify which competencies contribute the most to the growth of the businesses. Competencies were related to management, identifying and exploiting opportunities, asserting one's position in a network of companies, intensive work and mastering the functional and technical aspects related to business. But, this study indicates that only managerial and networking competencies have a positive impact on business growth. However, there is no significant impact for the competencies related to the identification and exploitation of opportunities, hard work, and technical \& functional skills on the growth of the business. We understand that during the early years, managerial competencies such as organization, coordination, leadership, problem-solving and control are crucial for building and developing the business. These results are in line with Gasse et al. (2004) who find that the mobilization of managerial competencies is crucial to ensure the functioning of the company's activities. In fact, these competencies are mainly mobilized in the management of routine activities and determine the sustainability of the business (Nkakleu et al., 2013). 
The link with networking competencies and the growth shows how much these competencies are important in boosting the business. Networking is vital: it facilitates the exchange of information with different economic partners and allows benefiting from mutual experiences to improve the entrepreneurial vision and strengthen the competitive position in market. According to Bah (2008), a good network is cultivated concerning size and weight. The result is in line with the work of numerous researchers (Kusumawardhani et al., 2009).

\section{Recommendations}

Today, the slowdown in the economic growth worldwide, even for developed countries, and its inability to cope with many economic and social problems has prompted governments to provide more support to the private sector, so entrepreneurs can bring more energizes for their economies. However, the alarming failure rates show that many entrepreneurs lack the competencies to sustain and grow their businesses. Through this work, we hope a better understanding of the entrepreneurs who have the profile for developing their projects to energize their environment and create wealth. This study could serve the various accompaniment structures of entrepreneurs to identify the most competent, to provide them with all the assistance they need, and thereby contribute to the emergence of a new generation of entrepreneurs able of meeting the challenges of the new economy. They are the best source of jobs, wealth and innovation, as confirmed by Stam et al. (2011) who find that the future now belongs to "ambitious entrepreneurship" which contributes most to economic growth.

\section{Conflicts of Interest}

The authors declare no conflicts of interest regarding the publication of this paper.

\section{References}

Bah, R. D. (2008). La réaction: Capital social des dirigeants et performance des entreprises. Revue des Sciences de Gestion, 231-232, 131-35. https://doi.org/10.3917/rsg.231.0131

Barba-Sánchez, V., \& Martínez-Ruiz, M. D. P. (2009). A Longitudinal Study to Assess the Most Influential Entrepreneurial Features on a New Firm's Growth. Journal of Small Business and Entrepreneurship, 22, 253-266. https://doi.org/10.1080/08276331.2009.10593454

Baron, R. A., \& Markman, G. D. (2003). Beyond Social Capital: The Role of Entrepreneurs' Social Competence in Their Financial Success. Journal of Business Venturing, 18, 41-60. https://doi.org/10.1016/S0883-9026(00)00069-0

Bayad, M., Boughattas, Y., \& Schmitt, C. (2007). Démarche d'identification et évaluation: Approche par référentiel compétences. Sherbrooke: Paper Presented at 5ème Congrès International de l'Académie de l'Entrepreneuriat. http://entrepreneuriat.com/congres-aei/5eme-congres-2007/

Bhardwaj, A. (2013). Managerial Competencies and Their Influence on Managerial Performance: A Literature Review. International Journal of Advanced Research in Man- 
agement and Social Sciences, 2, 70-84.

Boudreaux, C. J., Nikolaev, B. N., \& Klein, P. (2019). Socio-Cognitive Traits and Entrepreneurship: The Moderating Role of Economic Institutions. Journal of Business Venturing, 34, 178-196. https://doi.org/10.1016/j.jbusvent.2018.08.003

Brush, C. G., Ceru, D. J., \& Blackburn, R. (2009). Pathways to Entrepreneurial Growth: The Influence of Management, Marketing, and Money. Business Horizons, 52, 481-491. https://doi.org/10.1016/j.bushor.2009.05.003

Carrier, C., \& Tremblay, M. (2007). La recherche créative d'opportunités d'affaires: Compétence négligée des organismes québécois d'accompagnement à l'entrepreneuriat? Paper Presented at 5ème Congrès International de l'Académie de l'Entrepreneuriat. http://entrepreneuriat.com/congres-aei/5eme-congres-2007/

Chabaud, D., \& Sammut, S. (2016). Le dirigeant au coeur des dynamiques entrepreneuriales des PME . Revue de l'Entrepreneuriat, 1, 6-13. https://doi.org/10.3917/entre.151.0007

Chandler, G. N., \& Jansen, E. (1992). The Founder's Self-Assessed Competence and Venture Performance. Journal of Business Venturing, 7, 223-236. https://doi.org/10.1016/0883-9026(92)90028-P

Chandler, G. N., McKelvie, A., \& Davidsson, P. (2009). Asset Specificity and Behavioral Uncertainty as Moderators of the Sales Growth-Employment Growth Relationship in Emerging Ventures. Journal of Business Venturing, 24, 373-387. https://doi.org/10.1016/j.jbusvent.2008.04.002

Colombo, M. G., \& Grilli, L. (2010). On Growth Drivers of High-Tech Start-Ups: Exploring the Role of Founders Human Capital and Venture Capital. Journal of Business Venturing, 25, 610-626. https://doi.org/10.1016/j.jbusvent.2009.01.005

Das, M., \& Goswami, N. (2019). Effect of Entrepreneurial Networks on Small Firm Performance in Kamrup, a District of Assam. Journal of Global Entrepreneurship Research, 9, 1-14. https://doi.org/10.1186/s40497-018-0122-6

Davidsson, P., Achtenhagen, D., \& Naldic, L. (2007). What Do We Know about Small Firm Growth? International Handbook Series on Entrepreneurship, 3, 361-398. https://doi.org/10.1007/978-0-387-32313-8_13

Delmar, F., Davidsson, P., \& Gartner, W. B. (2003). Arriving at the High-Growth Firm. Journal of Business Venturing, 18, 189-216. https://doi.org/10.1016/S0883-9026(02)00080-0

Dobbs, M., \& Hamilton, R. T. (2007). Small Business Growth: Recent Evidence and New Directions. International Journal of Entrepreneurial Behaviour \& Research, 13, 296-322. https://doi.org/10.1108/13552550710780885

Duthil, G., \& Vanhaecke, D. (1993). Les fondements de l'économie d'entreprise. Éditions L'Harmattan.

Fayolle, A., Barbosa, S. D., \& Kickul, J. (2008). Une nouvelle approche du risque en création d'entreprise. Revue Française de Gestion, 185, 141-159. https://doi.org/10.3166/rfg.185.141-159

Fortin, P. A. (1992). Devenez entrepreneur. Pour un Québec plus entrepreneurial. Les Presses de l'Université Laval.

Gartner, W. B. (1989). Who Is the Entrepreneur? Is the Wrong Question? American Journal of Small Business, 12, 11-31. https://doi.org/10.1177/104225878801200401

Gasse, Y., \& d'Amboise, G. (1998). La croissance réussie des PME: Une question de compétences et de régie. Gestion, 23, 41-47.

Gasse, Y., Diochon, M., \& Menzies, T. V. (2004). Les entrepreneurs émergents dont l'entreprise est devenue opérationnelle et les autres: Comparaisons lors de la conception 
du projet d'entreprise. Journal of Small Business and Entrepreneurship, 17, 117-134. https://doi.org/10.1080/08276331.2004.10593316

Ge, B., Sun, Y., Chen, Y., \& Gao, Y. (2016). Opportunity Exploitation and Resource Exploitation: An Integrative Growth Model for Entrepreneurship. Internet Research, 26, 498-528. https://doi.org/10.1108/IntR-04-2015-0123

GEM Global Entrepreneurship Monitor (2018). GEM 2017/2018 Global Report. http://www.gemconsortium.org/report/gem-2018-2019-global-report

Hawi, R. O., Alkhodary, D., \& Hashem, T. (2015). A Managerial Competencies and Organizations Performance. International Journal of Management Sciences, 5, 723-735.

Human, S. E., \& Provan, K. G. (1994). An Emergent Theory of Structure and Outcomes in Small Firms Strategic Manufacturing Networks. Academy Management Journal, 40, 368-403. https://doi.org/10.2307/256887

Janssen, F. (2005). La conceptualisation de la croissance: L'emploi et le chiffre d'affaires sont-ils des représentations interchangeables d'un même phenomena (pp. 267-291)? Gestion.

Janssen, F. (2011). Les déterminants de la croissance des P.M.E.: Analyse théorique et étude empirique auprès d'un échantillon d'entreprises belges. Editions Universitaires Européennes

Kellermanns, F. W., Eddleston, K. A., Barnett, T., \& Pearson, A. (2008). An Exploratory Study of Family Member Characteristics and Involvement: Effects on Entrepreneurial Behavior in the Family Firm. Family Business Review, 21, 1-14. https://doi.org/10.1111/j.1741-6248.2007.00107.x

Kiggundu, M. N. (2002). Entrepreneurs and Entrepreneurship in Africa: What Is Known and What Needs to Be Done. Journal of Developmental Entrepreneurship, 7, 239-58.

Königová, M., Urbancová, H., \& Fejfar, J. (2012). Identification of Managerial Competencies in Knowledge-Based Organizations. Journal of Competitiveness, 4, 129-142. https://doi.org/10.7441/joc.2012.01.10

Kusumawardhani, A., McCarthy, G., \& Perera, N. (2009). Framework of Entrepreneurial Orientation and Networking: A Study of SMEs Performance in a Developing Country. Paper Presented at Sydney Business School. http://ro.uow.edu.au/gspapers/23/

Lambert, T. E. (2019). Monopoly Capital and Entrepreneurship: Whither Small Business? Cambridge Journal of Economics, 43, 1577-1595. https://doi.org/10.1093/cje/bey060

Lindič, J., Bavdaž, M., \& Kovačič, H. (2012). Higher Growth through the Blue Ocean Strategy: Implications for Economic Policy. Research Policy, 41, 928-938. https://doi.org/10.1016/j.respol.2012.02.010

Loufrani-Fedida, S., Hauch, V., \& Elidrissi, D. (2019). The Dynamics of Relational Competencies in the Development of Born Global Firms: A Multilevel Approach. International Business Review, 28, 222-237. https://doi.org/10.1016/j.ibusrev.2018.09.001

Man, T. W. Y., Lau, T., \& Snape, E. D. (2008). Entrepreneurial Competencies and the Performance of Small and Medium Enterprises: An Investigation through a Framework of Competitiveness. Journal of Small Business and Entrepreneurship, 21, 257-276. https://doi.org/10.1080/08276331.2008.10593424

Moore, W. M. (1993). A Realistic Assessment of Human Resource Projections for Small Firms: The Role and Implication of Size. Journal of Business and Entrepreneurship, 5, 77-86.

Mowll, C. A. (1989). Successful Management Based on Key Principles. Healthcare Financial Management, 43, 122-123. 
Ndjambou, R., \& Sassine, M. S. (2014). Étude de la relation entre profil du dirigeant, culture et performance des PME gabonaises: Clarification des compétences et de la vision. La Revue Gestion et Organisation, 6, 7-19. https://doi.org/10.1016/j.rgo.2014.01.001

Nkakleu, R. (2018). Les petites entreprises et leur accompagnement performant: Une approche par les compétences. In Editions EMS, Accompagnement des petites entreprises au Cameroun et au Sénégal (pp. 119-134). Collection: Questions de société.

Nkakleu, R., Tidjani, B., Mefoute, A., \& Biboum, A. D. (2013). Compétences des entrepreneurs et performance des $P M E$ en démarrage: La structure d'accompagnement a-t-elle un impact? Une comparaison Cameroun-Sénégal. Paper Presented at XXII Conférence Internationale de Management Stratégique. https://www.strategie-aims.com

Nuscheler, D., Engelen, A., \& Zahra, S. A. (2019) .The Role of Top Management Teams in Transforming Technology-Based New Ventures' Product Introductions into Growth. Journal of Business Venturing, 34, 122-140.

https://doi.org/10.1016/j.jbusvent.2018.05.009

Paturel, R. (1997). Pratique du management stratégique. Grenoble: Edition Presses Universitaires de Grenoble.

Sabai, K., \& Tau, H. L. (2018). Entrepreneurial Opportunity Recognition, Exploitation and New Venture Success: Moderating Role of Prior Market and Technology Knowledge. International Journal of Entrepreneurship, 22, 1-6.

https://www.abacademies.org/abstract/entrepreneurial-opportunity-recognition-exploitat ion-and-new-venture-success-moderating-role-of-prior-market-and-technol-7793.html

Sajilan, S., \& Tehseen, S. (2019). Network Competence and Firm Performance: The Mediating Role of Entrepreneurial Innovativeness among Malaysian Chinese Entrepreneurs of Wholesale Businesses. Asian Academy of Management Journal, 24, 187-201. https://doi.org/10.21315/aamj2019.24.s1.13

Scuotto, V., Del Giudice, M., Tarba, S., Messeni, P. A., \& Chang, V. (2019). International Social SMEs in Emerging Countries: Do Governments Support Their International Growth? Journal of World Business.

Shelton, L. M. (2006). Female Entrepreneurs, Work-Family Conflict, and Venture Performance: New Insights into the Work-Family Interface. Journal of Small Business Management, 44, 285-297. https://doi.org/10.1111/j.1540-627X.2006.00168.x

Stam, E., C. Hartog, A., Van, S., \& Thurik, R. (2011). Ambitious Entrepreneurship, High Growth Firms and Macroeconomic Growth. In M. Minniti (Ed.), The Dynamics of Entrepreneurship: Evidence from the Global Entrepreneuership Monitor Data (pp. 231-249). Oxford: Oxford University Press. https://doi.org/10.1093/acprof:oso/9780199580866.003.0011

Teece, D. J., Pisano, G., \& Shuen, A. (1997). Dynamic Capabilities and Strategic Management. Strategic Management Journal, 18, 509-533. https://doi.org/10.1002/(SICI)1097-0266(199708)18:7<509::AID-SMJ882>3.0.CO;2-Z

Woywode, M., \& Lessat, V. (2001). Les facteurs de succès des entreprises à croissance rapide en Allemagne. Revue Internationale PME, 14, 17-43.

https://doi.org/10.7202/1008696ar

Zhao, L., \& Aram, J. D. (1995). Networking and Growth of Young Technology-Intensive Ventures in China. Journal of Business Venturing, 10, 349-370.

https://doi.org/10.1016/0883-9026(95)00039-B 